\title{
PRINSIP-PRINSIP AKUNTANSI SYARIAH DALAM MENJAGA AKUNTABILITAS LAPORAN KEUANGAN TAHUN 2015 PADA PT. BANK MANDIRI SYARIAHKOTA PALOPO
}

\author{
Muh. Yusuf $\mathbf{Q}^{\mathbf{1}^{*}, \text { Suhardi M. Anwar }}{ }^{1}$, Sunarti ${ }^{1}$ \\ 1Sekolah Tinggi Ilmu Ekonomi Muhammadiyah Palopo \\ *yusufQ@stiem.ac.id
}

\begin{abstract}
This study aims to determine and analyze Sharia accounting principles in maintaining the accountability of 2015 financial statements at PT. Bank Mandiri Syariah Palopo City. Sharia accounting principles in maintaining the accountability of 2015 financial statements at PT. Bank Mandiri Syariah Palopo City is quite good, this is due to the existence of openness, good accountability, responsibility, professionalism and fairness in the financial statements are very suitable with the percentage of $47 \%$ is in frequency 14 of the total 30 respondents. Their reason is that with the existence of accountability and good in a company, all of their employees will be satisfied with the responsibilities given.
\end{abstract}

Keywords: Principles of Syariah Accounting and Accountability of Financial Statements

\begin{abstract}
Abstrak
Penelitian ini bertujuan untuk mengetahui dan meganalisis prinsip-prinsip akuntansi Syariah dalam menjaga akuntabilitas laporan keuangan tahun 2015 pada PT. Bank Mandiri Syariah Kota Palopo. Prinsip-prinsip akuntansi Syariah dalam menjaga akuntabilitas laporan keuangan tahun 2015 pada PT. Bank Mandiri Syariah Kota Palopo sudah cukup baik, hal ini disebabkan karena adanya keterbukaan, akuntabilitas yang baik, tanggung jawab, profesional dan kewajaran dalam laporan keuangan sangat sesuai dengan persentase $47 \%$ berada pada frekuensi 14 dari keseluruhan jumlah 30 responden. Alasan mereka bahwa dengan adanya akuntabilitas dan yang baik dalam suatu perusahaan maka semua karyawanya akan merasa puas dengan tanggung jawab yang diberikan.
\end{abstract}

Kata Kunci: Prinsip-Prinsip Akuntansi Syariah dan Akuntabilitas Laporan Keuangan

\section{PENDAHULUAN}

Pada dasarnya lembaga keuangan merupakan sebuah perantara di mana lembaga tersebut mempunyai fungsi dan peranan sebagai suatu lembaga yang menghimpun dana dari masyarakat dan menyalurkannya kepada masyarakat yang kekurangan atau membutuhkan dana agar terwujud masyarakat yang adil, makmur dan sejahtera.

Saat ini muncul lembaga keuangan syariah yang menjadi kompetitor dari lembaga keuangan konvensional. Menurut Sudarsono (2003) bank syariah adalah suatu lembaga keuangan yang usaha pokoknya memberikan kredit dan jasa-jasa lain dalam lalu lintas pembayaran serta peredaran uang yang menggunakan system dan operasinya berdasarkan prinsip-prinsip syariah. Artinya, operasi bank syariah tersebut didasarkan pada Al Qur'an dan Hadist. Sistem operasi bank syariah menggunakan sistem bagi hasil. ada berusaha untuk selalu meningkatkan kualitas dan kuantitas pelayanannya guna menarik nasabah baru dan menjaga loyalitas nasabah lama. Hal tersebut berlaku pula untuk perkembangan perbankan syariah saat ini yang semakin menunjukkan tren positif. Tidak hanya pasarnya yang semakin besar, perbankan syariah juga juga terus mengeluarkan berbagai produk unggulan yang diminati masyarakat. Konsepnya yang jauh dari riba dan sesuai dengan syariat islam, membuat produk perbankan syariah menjadi pilihan umat muslim di Indonesia yang berniat menjalankan agama islam secara kaffah.

Perkembangan industri perbankan syariah di Indonesia saat ini sudah mengalami peningkatan yang cukup pesat dan sudah memiliki tempat yang memberikan cukup pengaruh dalam lingkungan perbankan nasional. Keberadaan perbankan syariah ini dimulai pada saat penerbitan undang-undang No. 7 Tahun 1992 tentang perbankan, dimana undang-undang ini menjadi pendorong hadirnya sistem perbankan berbasis syariah. Dalam perkembangannya, undangundang tersebut akhirnya diganti ke dalam 


\section{Hal. 6-12}

undang-undang No. 10 Tahun 1998 yang menerangkan sistem perbankan syariah dengan lebih jelas dibandingkan undangundang sebelumnya. Dengan diberlakukannya undang-undang tersebut, perbankan di Indonesia dapat memberlakukan dual banking system atau sistem perbankan ganda, dimana bank konvensional dapat beroperasi berdampingan dengan bank syariah sebagai suatu unit usaha atau bank syariah yang berdiri sendiri. Namun, hal tersebut belum sepenuh mendorong pertumbuhan perbankan syariah yang sebenarnya karena masih terpengaruh kepada sistem perbankan konvensional, sehingga masih sering dipersamakan dengan bank konvensional.

Setelah berjalannya peraturan perbankan yang terakhir, akhirnya diterbitkan undang-undang yang lebih spesifik menerangkan tentang perbankan syariah yaitu undang-undang No. 21 Tahun 2008. Undang-undang ini menjadikan perbankan syariah sebagai landasan hukum yang jelas dari sisi kelembagaan dan sistem operasionalnya. Dengan kehadiran undangundang ini memicu peluang yang lebih besar yang diberikan kepada masyarakat untuk mendapatkan pelayanan perbankan sepenuhnya yang sesuai dengan syariat islam. Salah satunya adalah perbankan syariah menawarkan transaksi yang tidak berlandaskan pada konsep bunga, dapat diharapkan untuk lebih optimal melayani kalangan masyarakat yang belum dapat tersentuh oleh perbankan konvensional, dan memberikan pembiayaan dalam pengembangan usaha berdasarkan sistem syariat Islam. Menurut Karim (2010;7) berpendapat bahwa secara terminologi definisi syariah adalah:

"peraturan-peraturan dan hukum yang telah digariskan oleh Allah SWT, atau telah digariskan pokok-pokoknya dan dibebankan kepada kaum muslimin supaya mematuhinya, supaya syariah ini diambil oleh orang Islam sebagai penghubung diantaranya dengan Allah SWT dan di antaranya dengan manusia."

Dari definisi tersebut dapat disimpulkan bahwa syariah merupakan perintah dan larangan yang berbentuk
pISSN 2088-7485

peraturan-peraturan dan hukum yang menjadi pedoman dalam menjalani hidup dan sebagai penghubung antara diri sendiri dengan Tuhan Yang Maha Esa serta antara sesama manusia. Perbankan syariah menjalankan sistem operasionalnya dengan memberlakukan sistem bagi hasil (profit and lost sharing) dan berbagi resiko (risk sharing) dengan nasabahnya yang memberikan penjelasan atas setiap perhitungan keuangan atas transaksi yang dilakukan sehingga akan meminimalisir kegiatan spekulatif dan tidak produktif. Dalam ajaran Islam, sebuah transaksi yang melibatkan dua orang antara pembeli dan penjual tidak boleh ada yang merasa dirugikan. Keduanya harus dapat saling bekerja sama dan melakukan transaksi sesuai dengan kesepakatan yang menandakan bahwa tidak ada salah satu pihak yang merasa dirugikan karena kesepakatan tersebut merupakan sebuah akad (perjanjian) yang telah disetujui bersama.

Dalam hal produk-produk yang ditawarkan oleh bank syariah, produkproduk tersebut sebagian besar memiliki kesamaan dengan yang ditawarkan oleh bank konvensional. Namun, dalam hal penerapannya tentunya berbeda. Hal ini dikarenakan adanya perbedaan prinsip diantara keduanya. Beberapa produk dengan berbagai skim akad ditawarkan oleh bank syariah, diantaranya produk tabungan dengan akad Wadiah (titipan), jual-beli dengan akad Murabahah, sewa dengan akad Ijarah, bagi hasil dengan akad Mudharabah, penyertaan dengan akad Musyarakah, investasi dengan akad Mudharabah, serta produk jasa lainnya.

Dalam layanan perbankan syariah yang berhubungan dengan penyaluran dana seperti pemberian pembiayaan kepada nasabah, dapat dilakukan dengan berbagai bentuk akad sesuai dengan kebutuhan dari nasabah sendiri. Salah satu bentuk pembiayaan yang paling sering diberikan kepada nasabah adalah pembiayaan konsumtif untuk memenuhi kebutuhan konsumsi dari nasabah. Pembiayaan konsumtif terbagi dalam beberapa macam produk yang dapat dibiayai, mulai dari barang, mobil, barang-barang mewah, 

pada pembiayaan atas kepemilikan rumah atau umumnya dikenal dengan nama KPR (Kredit Kepemilikan Rumah) untuk lingkungan bank konvensional merupakan salah satu produk yang cukup diminati oleh nasabah bank syariah. Hal ini disebabkan setiap masyarakat tentunya ingin memiliki rumah mereka masing-masing sehingga, produk ini dapat dikatakan sebagai salah satu produk unggulan oleh bank syariah.

Pada penerapan pembiayaan kepemilikan rumah di bank syariah dapat dilakukan dengan berbagai akad, seperti akad jual-beli (Murabahah), jual-beli dengan pesanan khusus (Istishna), sewa-beli (Ijarah Muntahiyah Bittamlik), dan penyertaan-sewa (Musyarakah Muntanaqisah). Pada setiap akad memiliki karakteristik masing-masing yang menggambarkan kelebihan dan kekurangannya. Pada akad Murabahah (jual-beli) dan Ijarah Muntahiyah Bittamlik (IMBT/sewa-beli) khususnya, tentu memiliki tata cara dan keunikan masingmasing dalam pemberian pembiayaan.

\section{KAJIAN PUSTAKA DAN TEORI}

Bank merupakan lembaga keuangan yang bertugas menghimpun dana dari masyarakat dan menyalurkan kembali ke masyarakat guna memenuhi kebutuhan dana bagi pihak yang membutuhkan, juga berperan sebagai lembaga intermediasi/perantara bagi masyarakat yang kelebihan dana dan masyarakat yang kekurangan dana untuk memenuhi kebutuhannya baik untuk kegiatan produktif maupun konsumtif. Jenis bank menurut kegiatan usaha terdiri dari bank umum dan bank perkreditan rakyat. Pengertian bank umum menurut Wiroso (2005: 34), adalah sebagai berikut :

"Bank Umum adalah bank yang melaksanakan kegiatan secara konvensional dan atau berlandaskan prinsip syariah yang dalam kegiatannya memberikan jasa dalam lalu lintas pembayaran."

Dari pengertian di atas, dapat disimpulkan bahwa jenis bank berdasarkan kegiatan usahanya dapat dibedakan menjadi 2 yaitu bank konvensional dan bank syariah.

Pengertian bank syariah menurut Muhammad (2005), dijelaskan bahwa:

"Bank syariah adalah bank yang beroperasi dengan tidak mengandalkan pada bunga. Atau dengan kata lain, bank Islam adalah lembaga keuangan yang usaha pokoknya memberikan pembiayaan dan jasa-jasa lainnya dalam lalu lintas pembayaran serta peredaran uang yang pengoperasiannya disesuaikan dengan prinsip syariah."

Dari pengertian diatas, bank yang beroperasi berdasarkan prinsip svariah adalah bank yang menggunakan $\mathrm{r} \quad 8$ Islam yang bersumber dari Al Qur'an dan Al Hadist dalam melaksanakan kegiatan perbankannya. Melalui produk-produk yang dihasilkan oleh bank Islam atau bank syariah dalam produk pengumpulan dana tersebut dapat dioperasikan sesuai dengan ketentan ajaran Islam. Perbedaan utama antara kegiatan bank berdasarkan prinsip syariah dengan bank konvensional pada dasarnya terletak pada sistem pemberian imbalan atau jasa.

Dalam fungsinya sebagai penerima amanah bank syariah melakukan kegiatan penghimpunan dana dalam bentuk tabungan, giro dan deposito dengan prinsip wadiah dan mudharabah. Sebagai pengelola investasi bank syariah melaksanakan penyaluran dana dalam bentuk pembiayaan baik dengan menggunakan prinsip jual beli, bagi hasil dan sewa. Sebagai penyedia jasa keuangan dan lalu lintas pembayaran, bank syariah melakukan kegiatan jasa seperti wakalah, kafalah, sharf, qardh, hiwalah, rahn dan lainnya. Sebagai pelaksana kegiatan sosial, bank syariah melakukan penghimpunan dan penyaluran dana kebajikan bentuk qardhul hasan dan zakat, infak dan shadaqah.

Menurut Islamic Studies of Economics Group (2007), bank syariah mempunyai fungsi sebagai penerima amanah untuk melakukan investasi perdagangan dan jasa (Mudharib), sebagai pengelola investasi yang dikehendaki oleh pemilik dana (Shahibul maal), sebagai penyedia jasa lalu lintas pembayaran sebagaimana pada umumnya dijalankan oleh bank konvensional sepanjang tidak bertentangan 
dengan prinsip syariah dan ebagai pengelola ZIS dan fungsi sosial lainnya."

Adanya bank syariah diharapkan dapat memberikan sumbangan terhadap pertumbuhan ekonomi masyarakat melalui pembiayaan-pembiayaan yang diberikan. Melalui pembiayaan ini bank syariah dapat menjadi mitra dengan nasabah, sehingga hubungan bank syariah dengan nasabah tidak lagi sebagai kreditur dan debitur tetapi menjadi hubungan kemitraan.

Bank syariah mempunyai peranan yang sangat strategis dalam mengembangkan perekonomian di Indonesia dengan mengkonsentrasikan pada perbaikan moral para pelaku keuangan, karena dengan cara ini perekonomian Indonesia akan bisa pulih. Salah satu penyebab krisis ekonomi yang melanda Indonesia salah satunya karena masalah moral para pelaku keuangan yang buruk.

\section{Pengertian Akuntansi Syariah}

Akuntansi merupakan bagian dari informsi yang tidak dapat pisahkan dari suatu gugusan tugas manajemen dalam mencapai tujuan terutama dalam pengawasan dan perencanaan, dalam fungsi pengawasan tugas akuntansi sangat strategis yaitu : sebagai alat pembanding dan rencana. Adapun maksud dari pembanding dsisini yaitu dimaksudkan untuk mengetahui penyimpangan (murabahah) yang terjadi sehingga mananjemen dapat dengan mudah melakukan perbaikan, penilaian atau koreksi secara lebih dini.

Sedangkan pengertian akuntansi syariah menurut Muhammad (2002) "Akuntansi syariah adalah akuntansi yang dikembangkan dan bukan hanya dengan tambal sulam terhadap akuntansi konvensional, akan tetapi merupakan pengembangan filosofis terhadap nilai-nilai alqur'an yang dikeluarkan dalam pemikiran teoritis dan teknis akuntansi.

Dengan demikian akuntansi syariah dapat diartikan suatu informasi keuangan yang dipakai suatu perusahaan untuk pengambilan suatu keputusan yang berdasarkan pada syariat Islam

Jika kita cermati surat Al-Baqarah ayat 282, Allah memerintahkan untuk melakukan penulisan secara benar atas segala transaksi yang pernah terjadi selama melakukan muamalah. Dari hasil penulisan tersebut dapat digunakan sebagai informasi untuk menentukan apa yang akan diperbuat oleh seseorang. Sehubungan dengan ini, beberapa definisi akuntansi dapat disajikan, diantaranya: Littleton mendefinisikan, tujuan utama dari akuntansi adalah untuk melaksanakan perhitungan periodik antara biaya (usaha) dari hasil (prestasi). Konsep ini merupakan inti dari teori akuntansi dan merupakan ukuran yang dijadikan sebagai rujukan dalam mempelajari akuntansi.

APB (Accounting Principle Board) Statement No. 4 mendefinisikan debagai berikut "akuntansi adalah suatu kegiatan jasa. Fungsinya adalah memberikan informasi kuantitatif, umumnya dalam ukuran uang mengenai suatu badan ekonomi yang dimagsud untuk digunakan dalam pengambilan keputusan ekonomi, yang digunakan dalam memilih di antara beberapa alternatif"

AICPA (American Institute of Certified Public Accountant) mendefinisikan sebagai berikut: " Akuntansi adalah seri pencatatan, penggolongan, dan pengikhtisaran dengan cara tertentu dan dalam ukuran moneter, transaksi dan kejadian umumnya bersifat keuangan dan termasuk menafsirkan hasilnya.

Dalam keterangan ini penulis menyimpulkan bahwa pengertian Akuntansi Syari'ah jika ditinjau dari secara etimologi , kata akuntansi berasal dari bahasa inggris, accounting, dalam bahasa Arabnya disebut “ Muhasabah" yang berasal dari kata hasaba, hasiba, muhasabah atau wazan yang lain adalah hasaba, hasban, hisabah, artinya menimbang, memperhitungkan mengkalkulasikan, mendata, atau menghisab, yakni menghitung dengan seksama atau teliti yang harus dicatat dalam pembukuan tertentu

Menurut Sofyan S. Harahap (2003) dalam (Akuntansi Social ekonomi dan Akuntansi Islam hal 56 ) mendefinisikanAkuntansi Islam atau Akuntansi syariah pada hakekatnya adalah penggunaan akuntansi dalam menjalankan syariah Islam. Akuntansi syariah ada dua versi, Akuntansi syariah yang yang secara 

Islami khususnya pada era Nabi SAW, Khulaurrasyidiin, dan pemerintah Islam lainnya. Kedua Akuntansi syariah yang saat ini muncul dalam era dimana kegiatan ekonomi dan sosial dikuasai ( dihegemony) oleh sistem nilai kapitalis yang berbeda dari sistem nilai Islam. Kedua jenis akuntansi itu bisa berbeda dalam merespon situasi masyarakat yang ada pada masanya. Tentu akuntansi adalah produk masanya yang harus mengikuti kebutuhan masyarakat akan informasi yang disuplinya.

\section{Prinsip dalam Akuntansi Syariah}

Nilai pertanggungjawaban, keadilan dan kebenaran selalu melekat dalam sistem akuntansi syari'ah. Ketiga nilai tersebut tentu saja telah menjadi prinsip dasar yang universal dalam operasional akuntansi syari'ah. Apa makna yang terkandung dalam tiga prinsip umum tersebut? Berikut uraian ketiga prinsip yang terdapat dalam surat AlBaqarah: 282.

\section{Pengertian Kuntabilitas}

Akuntabilitas publik merupakan suatu bentuk pertanggungjawaban atas segala bentuk aktivitas yang dilakukan oleh seseorang pemegang amanah terhadap orang atau badan yang meminta pertanggungjawaban tersebut. Akuntabilitas ini dilakukan sebagai bentuk transparansi daripada kegiatan operasional suatu perusahaan. Menurut Mardiasmo dalam bukunya "Akuntansi Sektor Publik" menyatakan bahwa:

"Akuntabilitas publik adalah kewajiban pihak pemegang amanah (agent) untuk memberikan pertanggungjawaban, menyajikan, melaporkan, dan mengungkapkan segala aktivitas dan kegiatan yang menjadi tanggungjawabnya kepada pihak pemberi amanah (principal) yang memiliki hak dan kewenangan untuk meminta pertanggungjawaban tersebut". (2002). Makna atau pengertian akuntabilitas dilihat dari aspek manajemen pemerintah adalah sebagai berikut:

Menurut Tim Studi Akuntabilitas Kinerja Instansi Pemerintah-BPKP, seperti yang dikutip oleh Ihyaul Ulum MD (2009) dalam bukunya "Sebuah Pengantar Akuntansi Sektor Publik" adalah:

"Akuntabilitas adalah perwujudan kewajiban untuk mempertanggung jawabkan keberhasilan atau kegagalan atas pelaksanaan misi organisasi dalam mencapai tujuan-tujuan dan sasaransasaran yang telah ditetapkan melalui suatu media pertanggungjawaban secara periodik". (2004)

Dari penjelasan diatas dapat ditarik kesimpulan bahwa akuntabilitas bertujuan untuk memberikan pertanggungjawaban kepada masyarakat atas dana yang digunakan pemerintah untuk meningkatkan kinerja pemerintah dalam peningkatan pemberian pelayanan kepada masyarakat.

Sasaran pertanggungjawaban ini adalah laporan keuangan yang disajikan dan peraturan perundang-undangan yang berlaku yang mencakup penerimaan, penyimpanan, dan pengeluaran uang oleh instansi pemerintah. Dengan dilaksanakannya ketiga komponen tersebut dengan baik akan dihasilkan suatu informasi yang dapat diandalkan dalam pengambilan keputusan, informasi tersebut akan tercermin didalam laporan keuangan yang merupakan media pertanggungjawaban. Integritas keuangan, pengungkapan dan ketaatan terhadap peraturan perundang-undangan menjadi indikator dari akuntabilitas keuangan.

\section{METODE}

\section{Waktu dan Lokasi Penelitian}

Adapun yang menjadi lokasi penelitian adalah PT. Bank Syariah Muamalat di Jalan dan waktu yang digunakan dalam penelitian ini kurang lebih dua bulan Juli sampai dengan bulan Juni 2016.

\section{Metode Pengumpulan Data}

Adapun metode pengumpulan data yang digunakan dalam penelitian ini yaitu Observasi (pengamatan langsung), Interview (wawancara), Dokumentasi,.Kuisioner, yaitu membagikan angket atau kuisioner kepada responden.untuk membuktikan kebenaran hipotesis yang telah dikemukakan di atas, maka metode analisis yang digunakan dalam penelitian adalah metode analisis deskriptif kualitatif yang metode yang dilakukan dengan cara mengklarifikasikan, 
menyusun, dan diinterpretasiakan dan kemudian dianalisis sehingga akan memberikan gambaran yang jelas mengenai prinsip akuntansi dan system pengolahan akuntansi keuangan.

\section{HASIL DAN PEMBAHASAN}

Prinsip akuntansi syari'ah adalah aturan keputusan umum yang diturunkan dari tujuan laporan keuangan dan konsep dasar akuntansi syariah yang mengatur pengembangan teknik akuntansi syariah. di bawah ini adalah prinsip-prinsip akuntansi syariah berikut penjelasannya.

Prinsip pengungkapan penuh (full disclosure principle)

Prinsip ini mengharuskan laporan keuangan akuntansi untuk mengungkapkan hal-hal yang penting agar laporan tersebut tidak menyesatkan. Hal ini dimaksudkan untuk menunjukkan pemenuhan hak dan kewajiban kepada Allah, masyarakat dan individu yang berkepentingan dengan perusahaan. Dengan demikian akuntansi syariah dilandasi oleh nilai kejujuran dan kebenaran sebagaimana telah diperintahkan Allah SWT . “..hendaklah seorang penulis diantara kamu menuliskan dengan benar dan janganlah penulis enggan menuliskannya sebagaimana Alloh telah mengajarkannya maka hendaklah ia menulis.

Prinsip konsistensi (consistency principle)

Prosedur akuntansi yang digunakan oleh suatu entitas harus sesuai untuk pengukuran posisi dan kegiatannya dan harus dianut secara konsisten dari waktu ke waktu, sesuai dengan prinsip yang dijabarkan oleh syari'ah. Penekanan pada konsisten terhadap prinsip yang sesuai dengan syari'ah berarti tak ada konsisten terhadap prinsip yang tidak sesuai dengan syari'ah.

Prinsip dasar akrual (accrual basis principle). Akrual (accrual) diartikan sebagai proses proses pengakuan non kas dan keadaannya pada saat terjadinya. Akrual mengakibatkan pengakuan pendapatan berarti peningkatan kewajiban sebesar jumlah tertentu yang diterima atau dibayar (biasanya berbentuk cash) di masa depan. Penentuan hasil usaha periodic dan posisi keuangan perusahaan dipengaruhi oleh metode pengakuan dan pengukuran atas sumber-sumber ekonomi dan kewajiban perusahaan, serta seluruh perubahannya pada saat transaksi itu terjadi (accrual basis), bukan pada saat realisasi penerimaan atau pengeluaran uang (cash basis). Dasar akrual ini berhubungan erat dengan postulat periode akuntansi. Dengan kata lain, pengaplikasian dasar akrual merupakan konsekuensi dari ponsulat periode akuntansi.

\section{Analisis Hasil Penelitian}

\section{Laporan Pertanggung Jawaban Keuangan}

Penilaian dan pengukuran harta, utang, modal laba, serta elemen-elemen lain laporan keuangan akuntansi syari;ah, menggunakan nilai tukar yang sedang berlaku. Imam Malik, mengenai hal ini, berpendapat bahwa dalam syarikah mudarabah, jika pemilik harta ingin melakukan perhitungan harta sebelum semua barang terjual, yang dinilai adalah barang-barang yang masih trsisa berdasarkan harga jual waktu itu dan penghitungan dilakukan dengan cara seperti ini. Namun pada barang yang masih mempunyai pasar, barang-barang ini dinilai berdasarkan nilai jual yang mungkin.

Prinsip penandingan menyatakan bahwa beban (expense) harus diakui pada periode yang sama dengan pendapatan (revenue). Hubungan baik dapat dicapai ketika hubungan tersebut menggambarkan hubungan sebab-akibat antara pendapatan dan biaya. Berdasarkan hasil penelitian dengan menggunakan kuisioner menjelaskan bahwa akuntasibilitas laporan keuangan pada PT. Bank Mandiri Syariah Kota Palopo kewajibankewajiban dari individu-individu atau penguasa yang dipercaya untuk mengelola sumber daya public. berikut akan dijelaskan dalam tabel 1 .

Berdasarkan data pada tabel 1 menjelaskan tentang tanggapan responden mengenai Pengambilan Keputusan Pembiayaan Bank Memakai Prinsip-Prinsip Party Atau Golongan pada bank mandiri di Kota Palopo, hal tersebut dibuktikan jawaban responden paling tinggi dengan skor 5 kategori jawaban sangat sesuai dengan persentase $46,67 \%$ berada pada frekuensi 14 dari keseluruhan jumlah 30 responden. Alasan mereka bahwa dengan pengambilan keputusan pembiayaan bank memakai prinsip-prinsip Party Atau Golongan 


\section{Hal. 6-12}

pada bank mandiri di Kota Palopo akan memberikan kejelasan dalam pengambilan keputusan keuangan perusahaan.

Tabel 1 Tanggapan Responden Tentang Laporan Pertanggung Jawaban Keuangan Dapat Digunakan Untuk Membandingkan Hasil Pencapaian pada bank mandiri di Kota Palopo

\begin{tabular}{llcc}
\hline & & $\begin{array}{c}\text { Tanggapa } \\
\text { n } \\
\text { R }\end{array}$ & Persenta \\
$\mathbf{N}$ & Kategori & $\begin{array}{c}\text { Rend } \\
\text { en }\end{array}$ & \% \\
\hline 1 & Sangat Sesuai & 14 & 46.67 \\
2 & Sesuai & 9 & 30.00 \\
3 & Kurang Sesuai & 5 & 16.67 \\
4 & Ragu-ragu & 2 & 6.67 \\
& Sangat Tidak & & \\
5 & Sesuai & 0 & 0.00 \\
Jumlah & 30 & 100 \\
\hline
\end{tabular}

Sumber: Data Primer Hasil Olahan, 2016

Tabel 2 Tanggapan Responden Tentang laporan pertanggung jawaban keuangan bank mandiri bahwa keberlangsungan keuangan dapat diketahui dengan adanya transparansi keuangan.

\begin{tabular}{clcc}
\hline No & Kategori & $\begin{array}{c}\text { Tanggapan } \\
\text { Responden }\end{array}$ & Persentase \\
\hline 1 & Sangat & 11 & 37 \\
& Sesuai & 13 & 43 \\
2 & Sesuai & 4 & 13 \\
3 & Cukup & Sesuai & \\
4 & Tidak & 2 & 7 \\
5 & Sesuai & Jumlah & 30
\end{tabular}

Berdasarkan data pada tabel 12 menjelaskan tentang tanggapan responden tentang laporan pertanggung jawaban keuangan pada bank mandiri di Kota Palopo, hal tersebut dibuktikan jawaban responden paling tinggi dengan skor 4 kategori jawaban sangat sesuai dengan persentase $43 \%$ berada pada frekuensi 13 dari keseluruhan jumlah 30 responden. Alasan mereka bahwa dengan laporan pertanggung jawaban yang jelas pada bank mandiri di Kota Palopo maka akan mudah dalam pengambilan keputusan perusahaan dimasa yang akan datang.
eISSN 2684-9313

pISSN 2088-7485

Tabel 3 Tanggapan Responden Tentang laporan pertanggungjawaban keuangan Bank Mandiri Dapat Memenuhi Hutang Jangka Panjang

\begin{tabular}{|c|c|c|c|}
\hline No & Kategori & $\begin{array}{l}\text { Tanggapan } \\
\text { Responden }\end{array}$ & Persentase \\
\hline 1 & $\begin{array}{l}\text { Sangat } \\
\text { Sesuai }\end{array}$ & 10 & 33 \\
\hline 2 & Sesuai & 9 & 30 \\
\hline 3 & $\begin{array}{l}\text { Cukup } \\
\text { Sesuai }\end{array}$ & 7 & 23 \\
\hline 4 & $\begin{array}{l}\text { Tidak } \\
\text { Sesuai }\end{array}$ & 4 & 13 \\
\hline 5 & Jumlah & 30 & 100 \\
\hline
\end{tabular}

Sumber: Data Primer Hasil Olahan, 2016

Berdasarkan data pada tabel 10 menjelaskan tentang tanggapan responden laporan pertanggungjawaban keuangan Bank Mandiri Dapat Memenuhi Hutang Jangka Panjang Bank Memakai Prinsip-Prinsip Party Atau Golongan pada bank mandiri di Kota Palopo, hal tersebut dibuktikan jawaban responden paling tinggi dengan skor 5 kategori jawaban sangat sesuai dengan persentase 33\% berada pada frekuensi 10 dari keseluruhan jumlah 30 responden. Alasan mereka bahwa dengan laporan pertanggungjawaban keuangan yang jelas dalam suatu perusahaan maka memudahkan perusahaan dalam pengambilan keputusan yang tepat.

Tabel 4 Tanggapan Responden Tentang laporan bertanggungjawaban Keuangan dapat memenuhi Hutang jangka Pendek bank mandiri di Kota Palopo

\begin{tabular}{|c|c|c|c|}
\hline No & Kategori & $\begin{array}{l}\text { Tanggapan } \\
\text { Responden }\end{array}$ & Persentase \\
\hline 1 & $\begin{array}{l}\text { Sangat } \\
\text { Sesuai }\end{array}$ & 9 & 30 \\
\hline 2 & Sesuai & 14 & 47 \\
\hline 3 & $\begin{array}{l}\text { Cukup } \\
\text { Sesuai }\end{array}$ & 4 & 13 \\
\hline 4 & Tidak Sesuai & 3 & 10 \\
\hline 5 & Jumlah & 30 & 100 \\
\hline
\end{tabular}

Sumber: Data Primer Hasil Olahan, 2016

Berdasarkan data pada tabel 4 menjelaskan tentang tanggapan responden tentang laporan bertanggungjawaban Keuangan dapat memenuhi kebutuhan Hutang jangka Pendek bank pada mandiri di Kota Palopo, hal tersebut dibuktikan jawaban 
responden paling tinggi dengan skor 5 kategori jawaban sangat sesuai dengan persentase $46,67 \%$ berada pada frekuensi 14 dari keseluruhan jumlah 30 responden. Alasan mereka bahwa Pengambilan Keputusan Pembiayaan Bank Memakai Prinsip-Prinsip Party Atau Golongan pada bank mandiri di Kota Palopo, maka akan membawah dampak yang tidak baik bagi perusahaan.

Tabel 5 Tanggapan Responden Tentang Laporan Pertanggung Jawaban Anggaran Yang Telah Ditetapkan Dalam Menjalankan Operasionalnya Pada Bank Mandiri Di Kota Palopo

\begin{tabular}{clcc}
\hline No & Kategori & $\begin{array}{c}\text { Tanggapan } \\
\text { Responden }\end{array}$ & Persentase \\
\hline 1 & Sangat Sesuai & 12 & 40 \\
2 & Sesuai & 17 & 57 \\
3 & Cukup Sesuai & 1 & 3 \\
4 & Tidak Sesuai & 0 & 0 \\
5 & Jumlah & 30 & 100 \\
\hline
\end{tabular}

Sumber: Data Primer Hasil Olahan, 2016

Berdasarkan data pada tabel 10 menjelaskan tentang tanggapan responden Tentang Laporan Pertanggung Jawaban Anggaran Yang Telah Ditetapkan Dalam Menjalankan Operasionalnya pada Bank Mandiri di Kota Palopo, hal tersebut dibuktikan jawaban responden paling tinggi dengan skor 4 kategori jawaban sesuai dengan persentase $57 \%$ berada pada frekuensi 17 dari keseluruhan jumlah 30 responden. Alasan mereka bahwa dengan pelaporan Pertanggung Jawaban Anggaran Yang Telah Ditetapkan Dalam Menjalankan Operasionalnya Pada Bank Mandiri Di Kota Palopo

\section{Akuntabilitas Pengelolaan Keuangan}

Terjadinya krisis ekonomi disebabkan oleh tata cara penyelenggaraan pemerintahan yang tidak dikelola dan diatur dengan baik. Oleh karena itu, tata pemerintahan yang baik perlu segera dilakukan agar segala permasalahan yang timbul dapat segera dipecahkan dan juga proses pemulihan ekonomi dapat dilaksanakan dengan baik dan lancar. Disadari, mewujudkan tata pemerintahan yang baik membutuhkan waktu yang tidak singkat dan juga upaya yang terus menerus. Disamping itu, perlu juga dibangun kesepakatan serta rasa optimis yang tinggi dari seluruh komponen bangsa yang melibatkan tiga pilar berbangsa dan bernegara, yaitu para aparatur negara, pihak swasta dan masyarakat madani untuk menumbuhkembangkan rasa kebersamaan dalam rangka mencapai tata pemerintahan yang baik. Berdasarkan hasil penelitian menjelaskan bahwa Tanggapan Responden Tentang Keterbukaaan Laporan Keuangan pada Bank Mandiri di Kota Palopo. Untuk lebih jelasnya dapat dilihat pada tabel 6 berikut:

Tabel 6 Tanggapan Responden Tentang Keterbukaaan Laporan Keuangan pada Bank Mandiri di Kota Palopo

\begin{tabular}{clcc}
\hline No & Kategori & $\begin{array}{c}\text { Tanggapan } \\
\text { Responden }\end{array}$ & Persentase \\
\hline 1 & Sangat Sesuai & 12 & 40 \\
2 & Sesuai & 17 & 57 \\
3 & Cukup Sesuai & 1 & 3 \\
4 & Tidak Sesuai & 0 & 0 \\
5 & Jumlah & 30 & 100 \\
\hline
\end{tabular}

Sumber: Data Primer Hasil Olahan, 2016

Berdasarkan data pada tabel 10 menjelaskan tentang tanggapan responden keterbukaan laporan keuangan pada bank mandiri di Kota Palopo, hal tersebut dibuktikan jawaban responden paling tinggi dengan skor 4 kategori jawaban sesuai dengan persentase 57\% berada pada frekuensi 17 dari keseluruhan jumlah 30 responden. Alasan mereka bahwa dengan keterbukaan laporan keuangan pada bank mandiri di Kota Palopo, pimpinan perusaan akan mudah untuk mengambil ketusan dalam suatu perusahaan.

Tabel 7 Tanggapan Responden Tentang Pengambilan Keputusan Pembiayaan pada bank mandiri di Kota Palopo

\begin{tabular}{llcc}
\hline No & Kategori & $\begin{array}{c}\text { Tanggapan } \\
\text { Responden }\end{array}$ & Persentase \\
\hline 1 & Sangat Sesuai & 13 & 43 \\
2 & Sesuai & 12 & 40. \\
3 & Cukup Sesuai & 2 & 7 \\
4 & Tidak Sesuai & 3 & 10 \\
5 & Jumlah & 30 & 100 \\
\hline
\end{tabular}

Sumber: Data Primer Hasil Olahan, 2016

Berdasarkan data pada tabel 7 menjelaskan tentang tanggapan responden 
Pengambilan Keputusan Pembiayaan Bank Memakai Prinsip-Prinsip Party Atau Golongan pada bank mandiri di Kota Palopo, hal tersebut dibuktikan jawaban responden paling tinggi dengan skor 5 kategori jawaban sangat sesuai dengan persentase $43 \%$ berada pada frekuensi 13 dari keseluruhan jumlah 30 responden. Alasan mereka bahwa Pengambilan Keputusan Pembiayaan Bank Memakai Prinsip-Prinsip Party Atau Golongan pada bank mandiri di Kota Palopo.

Tabel 8 Tanggapan Responden Tentang Akuntabilitas pada bank mandiri di Kota Palopo

\begin{tabular}{llcc}
\hline No & Kategori & $\begin{array}{c}\text { Tanggapan } \\
\text { Responden }\end{array}$ & Persentase \\
\hline 1 & Sangat Sesuai & 14 & 47 \\
2 & Sesuai & 7 & 23 \\
3 & Cukup Sesuai & 5 & 17 \\
4 & Tidak Sesuai & 4 & 13 \\
5 & Jumlah & 30 & 100 \\
\hline
\end{tabular}

Sumber: Data Primer Hasil Olahan, 2016

Berdasarkan data pada tabel 10 menjelaskan tentang Akuntabilitas pada bank mandiri di Kota Palopo, hal tersebut dibuktikan jawaban responden paling tinggi dengan skor 5 kategori jawaban sangat sesuai dengan persentase $47 \%$ berada pada frekuensi 14 dari keseluruhan jumlah 30 responden. Alasan mereka bahwa dengan adanya akuntabilitas dan yang baik dalam suatu perusahaan maka semua karyawanya akan merasa puas dengan tanggungjawab yang diberikan.

Tabel 9 Tanggapan Responden Tentang Tanggung Jawab Karyawan pada bank mandiri di Kota Palopo

\begin{tabular}{clcc}
\hline No & Kategori & $\begin{array}{c}\text { Tanggapan } \\
\text { Responden }\end{array}$ & Persentase \\
\hline 1 & Sangat Sesuai & 11 & 37 \\
2 & Sesuai & 14 & 47 \\
3 & Cukup Sesuai & 4 & 13 \\
4 & Tidak Sesuai & 1 & 3 \\
5 & Jumlah & 30 & 100 \\
\hline
\end{tabular}

Sumber: Data Primer Hasil Olahan, 2016

Berdasarkan data pada tabel 10 menjelaskan tentang tanggung jawab karyawan pada bank mandiri di Kota Palopo, hal tersebut dibuktikan jawaban responden paling tinggi dengan skor 4 kategori jawaban sesuai dengan persentase $47 \%$ berada pada frekuensi 14 dari keseluruhan jumlah 30 responden. Alasan mereka bahwa dengan adanya tanggujawab yang baik dimiliki oleh suatu karyawan pada bank mandiri di Kota Palopo, maka segala aktivitas dapat berjalan dengan baik.

Tabel 10 Tanggapan Responden Tentang Profesional Dalam Pembuatan Laporan Keuangan pada Bank Mandiri di Kota Palopo

\begin{tabular}{clcc} 
No & Kategori & $\begin{array}{c}\text { Tanggapan } \\
\text { Responden }\end{array}$ & Persentase \\
\hline 1 & Sangat Sesuai & 13 & 43 \\
2 & Sesuai & 10 & 33 \\
3 & Cukup Sesuai & 4 & 13 \\
4 & Tidak Sesuai & 3 & 10 \\
5 & Jumlah & 30 & 100 \\
\hline
\end{tabular}

Sumber: Data Primer Hasil Olahan, 2016

Berdasarkan data pada tabel 10 menjelaskan tentang tanggapan responden Tentang Profesional Dalam Pembuatan Laporan Keuangan pada bank mandiri di Kota Palopo, hal tersebut dibuktikan jawaban responden paling tinggi dengan skor 5 kategori jawaban sangat sesuai dengan persentase $43 \%$ berada pada frekuensi 13 dari keseluruhan jumlah 30 responden. Alasan mereka bahwa dengan adanya sikap profesional dalam pembuatan laporan keuangan adalah hal yang sangat diharapkan oleh suatu perusahaan karena dengan laporan keuangan yang baik akan mudah untuk mengetahui kekurangan suatu perusahaan.

Tabel 11 Tanggapan Responden Tentang Kewajaran Laporan Keuangan pada Bank Mandiri di Kota Palopo

No Kategori $\begin{gathered}\text { Tanggapan } \\ \text { Responden }\end{gathered}$ Persentase

\begin{tabular}{clcc}
\hline 1 & Sangat Sesuai & 7 & 23 \\
2 & Sesuai & 8 & 27 \\
3 & Cukup Sesuai & 12 & 40 \\
4 & Tidak Sesuai & 3 & 10 \\
5 & Jumlah & 30 & 100 \\
\hline \multicolumn{4}{c}{ Sumber: Data Primer Hasil Olahan, 2016 } \\
\multicolumn{4}{c}{ Berdasarkan data pada tabel 10 } \\
menjelaskan tentang tanggapan responden
\end{tabular}


Tentang Kewajaran Laporan Keuangan pada Bank Mandiri di Kota Palopo, hal tersebut dibuktikan jawaban responden paling tinggi dengan skor 2 kategori jawaban cukup sesuai dengan persentase $40 \%$ berada pada frekuensi 12 dari keseluruhan jumlah 30 responden. Alasan mereka bahwa dengan adanya kewajaran dalam pembuatan laporan keuangan tersebut maka dapat dijadikan sebagai alat ukur sukses atau tidaknya suatu bank.

\section{PEMBAHASAN}

\section{Prinsip Tanggung Jawab Laporan Keuangan}

Berdasarkan prinsip-prinsip

syari'ah masalah akuntansi akan berkait pula dengan prinsip-prinsip syari'ah, karena syari'ah mencakup seluruh aspek kehidupan umat manusia, baik ekonomi, politik, sosial dan falsafah moral. Dengan demikian syari'ah berhubungan dengan seluruh aspek kehidupan manusia termasuk di dalam hal akuntansi mengemukakan beberapa syarat sebagai dasar-dasar akuntansi syari'ah, sebagai berikut: 1) benar (truth) dan sah (valid), 2) adil (justice), yang berarti menempatkan sesuatu sesuai dengan peruntukannya, diterapkan terhadap semua situasi dan tidak bias, harus dapat memenuhi kebutuhan minimum yang harus dimiliki oleh seseorang, kebaikan (benevolence/ihsan), harus dapat melakukan hal-hal yang lebih baik dari standar dan kebiasaan. Sebenarnya prinsipprinsip akuntansi konvensional telah mema-sukkan aspek-aspek seperti yang diutarakan di atas hanya saja prinsip conservatism yang selalu membela kepentingan pemilik modal menjadi tidak sejalan dengan prinsip-prinsip akuntansi syari'ah. Prinsip akuntansi syari'ah berdasarkan pengukuran dan penyingkapannya terdiri dari, 1) Zakat: penilaian bagian-bagian yang dizakati diukur secara tepat, dibayarkan kepada mustahik sesuai yang dikehendaki oleh AlQur'an (delapan asnaf) atau zakat dapat pula disalurkan melalui lembaga zakat yang resmi. 2) Bebas bunga: Entitas harus menghindari adanya bunga dalam pembebanan-pembebanan dari transaksi yang dilakukan, menghindari hal ini akan lebih tepat bila entitas berbentuk bagi hasil atau bentuk lain yang sifatnya tidak memakai instrumen bunga. 3) Halal: menghindari bentuk bisnis yang berhubungan dengan hal-hal yang diharamkan oleh syari'ah, seperti perjudian, alkohol, prostitusi, atau produk yang haram lainnya. Menghindari transaksi yang bersifat spekulatif, seperti bai' al-gharar; munabadh dan najash.

Prinsip akuntansi syari'ah berdasarkan pemegang kuasa dan pelaksana terdiri dari: 1) Ketaqwaan: mengakui bahwa Allah adalah penguasa tertinggi. Allah melihat setiap gerak yang akan diperhitungkan pada hari pembalasan. Dapat membedakan yang benar (al-haq) dan yang salah (al-bathil). Mendapatkan bimbingan dari Allah dalam pengambilan keputusan. Mencari ridha dan barakah Allah dalam menjalankan aktivitas. Merujuk dari investigasi yang dilakukan oleh Syahatah (2001:73-92) kaidah akuntansi yang terpenting berdasarkan hasil istimbath dari sumber-sumber hukum Islam (syari'ah), adalah Independensi jaminan keuangan. Perusahaan hendaklah mempunyai sifat yang jelas dan terpisah dari pemilik perusahaan, kesinambungan aktivitas. Kaidah ini memandang bahwa aktivitas suatu per-usahaan itu mesti berkesinambungan (terus beraktivitas), Hauliyah (pentahunan/penetapan periode). Sesuai dengan firman Allah dalam Al-Qur'an (9:36) "sesungguhnya bilangan bulan di sisi Allah ialah dua belas bulan jadi periode akuntansi syari'ah lebih tepat memakai putaran tahun, karena hal tersebut juga berhubungan dengan nisab zakat yang menggunakan bilangan tahun. Pembukuan langsung dan lengkap secara detail. Kaidah ini menghendaki pembukuan secara rinci dalam mencatat transaksi, dimuali dari tanggal, bulan, tahun, dan aktivitas-aktivitas yang dilakukan, hal ini disarkan perintah dalam Al-Qur'an (2:282) "uktubuhu" perintah mencatat kemudian "ila ajalin musamma" menunjukkan suatu tanggal kejadian tertentu.

\section{Prinsip Keadilan Laporan Keuangan}

Keadilan mengacu pada hubungan yang tidak dicurangi, ikhlas, dengan persetujuan yang matang atas proporsi masukan dan keluarannya. Kebersamaan mengacu pada prinsip saling 
menawarkan bantuan dan nasihat untuk saling meningkatkan produktivitas. Kegiatan bank syariah dalam hal penentuan harga produknya sangat berbeda dengan bank konvensional. Penentuan harga bagi bank syariah didasarkan pada kesepakatan antara bank dengan nasabah penyimpan dana sesuai dengan jenis simpanan dan jangka waktunya, yang akan menentukan besar kecilnya porsi bagi hasil yang akan diterima penyimpan. Berikut ini prinsipprinsip yang berlaku pada bank syariah. Pembiayaan berdasarkan prinsip bagi hasil (mudharabah), Pembiayaan berdasarkan prinsip penyertaan modal (musharakah), Prinsip jual beli barang dengan memperoleh keuntungan (murabahah).

Pembiayaan barang modal berdasarkan sewa murni tanpa pilihan (ijarah). Pilihan pemindahan kepemilikan atas barang yang disewa dari pihak bank oleh pihak lain (ijarah wa iqtina). Dalam rangka menjalankan kegiatannya, bank syariah harus berlandaskan pada Alquran dan hadis. Bank syariah mengharamkan penggunaan harga produknya dengan bunga tertentu. Bagi bank syariah, bunga bank adalah riba. Dalam perkembangannya kehadiran bank syariah ternyata tidak hanya dilakukan oleh masyarakat muslim, akan tetapi juga masyarakat nonmuslim. Saat ini bank syariah sudah tersebar di berbagai negara-negara muslim dan nonmuslim, baik di Benua Amerika, Australia, dan Eropa. Bahkan banyak perusahaan dunia yang telah membuka cabang berdasarkan prinsip syariah. Contoh Bank Syariah di Indonesia yaitu Bank Muamalat Indonesia, Bank Syariah Mandiri.

\section{Prinsip Kebenaran Laporan keungan syariah}

Prinsip kebenaran tidak dapat dilepaskan dengan prinsip keadilan. Contoh: dalam akuntansi kita akan selalu dihadapkan pada masalah pengakuan, pengukuran, dan pelaporan. Aktivitas ini dapat dilakukan dengan baik apabila dilandaskan pada nilai kebenaran.Kebenaran akan dapat menciptakan keadilan dalam mengakui, mengukur \& melaporkan transaksitransaksi ekonomiBerdasarkan uraian tentang laporan keuangan dapatlah kita temukan bahwa kebenaran yang terkandung didalamnya adalah kebenaran yang ditentukan oleh ikhtiar manusia yang sifatnya bisa terjadi bila ada syarat tertentu yang menguatkannya dan jika tidak ada yang menguatkannya maka hal tersebut menjadi tidak benar, ini sejalan dengan prinsip akuntansi yang mengharuskan adanya dokumen sebagai bukti transaksi. Apabila dihubungkan dengan teori korespondensi laporan keuangan ini mengandung kebenaran, yakni adanya kesesuaian antara angka-angka yang tertera dalam laporan keuangan dengan bikti-bukti transaksi yang mendasarinya. Kita tahu pembuatan laporan keuangan tidak memiliki nilai manfaat dan sah (utility and validity) jika tidak sesuai dengan bukti transaksi. Menurut teori konsistensi (koherensi) laporan keuangan memiliki nilai kebenaran, mengingat laporan keuangan dibuat berdasarkan prinsif dasar tertentu yaitu standar akuntansi keuangan dimana standar tersebut telah diakui kebenarannya baik dalam dunia professionalisasi akuntansi sendiri maupun oleh semua pihak dalam dunia usaha termasuk legalitas dari penguasa. Teori konsistensi memiliki statement bahwa sesuatu dianggap benar bila pernyataan itu bersifat koheren atau konsisten dengan pernyataan sebelumnya yang dianggap benar. Mengingat proses akuntansi memiliki unsur konsistensi dengan pola dan mekanisme baku maka laporan keuangan memiliki keuangan menurut teori koherensi (konsistensi). Kaum pragmatis mengungkapkan bahwa sesuatu dikatakan benar bergantung kepada berpaedah tidaknya sesuatu tersebut bagi kehidupan manusia bukanlah dikatakan kebenaran melainkan omong kosong belaka (William James). Laporan keuangan adalah informasi bisnis bagi para pemakai dengan maksud untuk mengambil keputusan ekonomi yang realistis dan prespektif, oleh karenanya laporan keuangan harus memberikan karakteristik pokok sehingga informasi yang dihasilkan memenuhi keandalan (realible) bagi para pengambil keputusan, dengan demikian kebenaran laporan keuangan relevan dengan yang diungkapkan teori pragmatis. 
Mardiasmo. 2005. Akuntansi Sektor Publik Edisi

\section{SIMPULAN}

Berdasarkan hasil penelitian menjelaskan bahwa prinsip pertanggung jawaban merupakan konsep yang tidak asing lagi dikalangan masyarakat muslim. Pertanggungjawaban selalu berkaitan dengan konsep amanah. Bagi kaum muslim, persoalan amanah merupakan hasil transaksi manusia dengan sang khalik mulai dari alam kandungan.Dari hasil analisis data menjelaskan bahwa prinsip keadilan, jika ditafsirkan lebih lanjut, surat Al-Baqarah; 282 mengandung prinsip keadilan dalam melakukan transaksi. Prinsip keadilan ini tidak saja merupakan nilai penting dalam etika kehidupan sosial dan bisnis, tetapi juga merupakan nilai inheren yang melekat dalam fitrah manusia.Hasil penelitian menjelaskan bahwa prinsip kebenaran, prinsip ini sebenarnya tidak dapat dilepaskan dengan prinsip keadilan. Sebagai contoh, dalam akuntansi kita kan selalu dihadapkan pada masalah pengakuan, pengukuran laporan. Dengan demikian pengembangan akuntansi Islam, nilai-nilai kebenaran, kejujuran dan keadilan harus diaktualisasikan dalam praktik akuntansi. Secara garis besar, bagaimana nilai-nilai kebenaran membentuk akuntansi syariah dapat diterangkan.

\section{DAFTAR PUSTAKA}

Ascarya,2007. "Akad dan produk bank syariah". Jakarta : PT. Raja Grafindo Persada

AdiwarmanKarim. (2010). Ikatan Akuntansi Indonesia. Jakarta: PT Gramedia Pustaka Utama

Harahap, Sofyan Safri, 2003. Teori Akuntansi, Edisi Kelima, PT. Raspindo,. Jakarta.

Ihyaul Ulum. 2009. Audit Sektor Publik Suatu Pengantar. Jakarta: Penerbit Bumi. Aksara.

Jusup AL. Haryono, 2005, Dasar-Dasar Akuntansi Ed. 5, STIE YKPN, Yokyakarta.

Karim, Hadiwarman, 2001 Bank, Jakarta: Preneda, Media Yogyakarta

Kasmir, 2010, Manajemen Perbankan, Cetakan di Kharisma, Jakarta
Mahmudi. (2005). Manajemen Kinerja Sektor Publik. Yogyakarta: UPP AMP YKPN

Muhammad: 2002, Bank Syari'ah dan Teori ke Prakteknya, Jakarta: Gema Insani Press Tazkia Institute. Chapra, Umer, 2001, The Future of Economics.

Triyuwono, M Ismail, AF Rahman 2007 Pembebas Sistem Pendidikan Tinggi Akuntansi. I Triyuwono. MT Abusharba, I Triyuwono.

Sudarsono Heri 2003, Bank Dan Lembaga Keuangan Syariah, Ekonisia, Yogyakarta,. 2003. Daud Ali Mohammad, Hukum Islam

Sohn Omar Abdullah 2010 von seinem Vater die Führung der JKNC. Omar Abdullah war zeitweilig Staatssekretär im

Wiroso, 2005. Penghimpun Dana dan Distribusi Hasil Usaha Bank. Syariah, PT. Grasindo, Jakarta.

Soemarso, 2008. Uang dan Bank Edisi 6 Yogyakarta

Simamora, Henry, 2002, Akuntanasi Basis Pengambilan Bisnis, Salemba Empat, Jakarta.

Sumitro, Djojohadikusomo, 2006,Indonesia dalam Pembangunan Dunia Kini dan

Standar Akuntansi Keuangan (SAK) No. 23, paragrap 01 poin (c) yang menyatakan bahwa pendapat juga timbul dari transaksi dan peristiwa ekonomi berikut ini : (c) penggunaan aktiva perusahaan oleh pihak-pihak lain yang menghasilkan bunga, royalti, dan deviden.

Surat Al-Baqarah ayat 282, Allah memerintahkan untuk melakukan penulisan secara benar atas segala transaksi yang pernah terjadi selama melakukan muamalah 